This is an accepted version of a final article first published by Sage in Latin American Perspectives, Vol. 43 No. 2, 190-206. Available at DOI: 10.1177/0094582X15616120

Accepted Version downloaded from SOAS Research Online: http://eprints.soas.ac.uk/22260/

\title{
State, State Institutions and Political Power in Brazil
}

\author{
Armando Boito \\ Department of Political Science \\ State University of Campinas, Brazil \\ armando.boito@gmail.com \\ Alfredo Saad-Filho \\ Department of Development Studies \\ SOAS, University of London, UK \\ as59@soas.ac.uk
}

\begin{abstract}
$\underline{\text { Abstract }}$
This article reviews the tensions, contradictions and conflicts in the ideologies and institutions of the Brazilian state during the Workers' Party administrations led by Luís Inácio Lula da Silva and Dilma Rousseff. The political conflicts during this period have been driven by disputes between two fractions of the country's bourgeoisie: the internal and the internationalized bourgeoisie. Their ideologies, policies, institutions and forms of political representation have determined government policies and outcomes. These processes have unfolded within an authoritarian democracy whose structures have not been challenged by the PT. The party's limited power and continuing timidity have facilitated an aggressive reaction of the internationalized bourgeoisie and the upper middle class, leading to a severe crisis in the administration of President Dilma Rousseff.
\end{abstract}


Keywords: Brazil, internal bourgeoisie, internationalized bourgeoisie, Workers' Party, Petrobras. 


\section{Biographical Information}

Armando Boito is professor of Political Science at the State University of Campinas, Brazil, editor of the journal Critica Marxista and participating editor of LAP. He researches Brazilian politics, labor movement and Marxism and has some articles published in the LAP about these issues.

Alfredo Saad-Filho is Professor of Political Economy at the School of Oriental and African Studies (SOAS), University of London, UK.

Corresponding author: Alfredo Saad-Filho, as59@soas.ac.uk, +44 207515634047. 


\section{Introduction}

This article examines the tensions, contradictions and conflicts in the ideologies and in the institutions of the Brazilian state during the Workers' Party (Partido dos Trabalhadores, PT) administrations led by Presidents Luís Inácio Lula da Silva (2003-2006, 2007-2010) and Dilma Rousseff (2011-2014, 2015-present). Those ideologies and institutions are studied as fields of engagement as well as tools of struggle in the conflicts between rival classes and class fractions in the dominant power bloc. In other words, ideologies and institutions serve as platforms - both material and ideational - supporting specific state policies. They can also serve as centers of resistance against policies favoured by rival interests within the power bloc, and vis-à-vis non-hegemonic forces outside it.

This does not imply that the Brazilian state is 'fragmented' as if its institutions could be (more or less randomly) captured by squabbling classes, fractions and interest groups competing on a (more or less level) playing field. For example, the working class, the trade union and peasant movements and the radical socialist parties, however defined, do not control any relevant institution of the state. Instead, the institutional, ideological, social and political conflicts in the country have been driven by disputes within the dominant power bloc, specifically, between two fractions of the bourgeoisie and their allies in the upper middle class. The other social groups have played a secondary role in these conflicts. The article also argues that state policies are not determined by the simple aggregation of selfish interests and the accommodation of contradictory short-term demands, which would bring continuous institutional instability and a zigzagging pattern of policy implementation. The outcome of the disputes between the two key fractions of the Brazilian bourgeoisie and the multiplicity of institutions under their control is largely determined by the interventions of the dominant institutions of the state. They include the Federal Executive and, at a further remove, Congress and the judicial system. These dominant institutions both drive and respond to demands from ministries, agencies, state-owned enterprises (SOEs), banks, the media, universities, NGOs, trade unions, political parties, and so on, all 
of which can advocate for and against specific policies, intervene in policy implementation, and contribute to broader struggles against rival interests.

In other words, while it is certainly true that the Brazilian state organizes the rule of the capitalist class, ${ }^{1}$ it does so through complex processes including tensions and displacements between rival social groups, whose interests are expressed in and through disputes within state institutions and between them and non-state institutions. This analytically rich approach can support a complex and contextual examination of the rule of capital in Brazil and the class nature of the state and its principal institutions, and it can inform an assessment of the strategies of the Brazilian left informed by Marxist political economy. This is done below in five sections. This introduction is the first. The second outlines the dominant power bloc in Brazil and describes the main fractions of the bourgeoisie and their allies. The third focuses on the key political forces and the fourth on the political regime, the composition of the key institutions of the state and the conflicts between them, and it shows how and why social conflicts can appear through disputes between institutions. The fifth reviews the role of lower-level of state institutions, and how these are used to advance or to block specific programmes and class platforms. The sixth section draws the relevant conclusions. 


\section{The Power Bloc}

The dominant power bloc in Brazil is polarised by complex relationships of cooperation and conflict both within and between two fractions of the large bourgeoisie. These fractions can be distinguished by their relationship with the process of accumulation in general and, specifically, with neoliberalism, international integration and financialization (Boito 2012, Filgueiras and Oliveira 2013, Saad-Filho 2014, Saad-Filho and Boito 2016).

This analysis of the material interests of broad social groups is not meant to map fixed class positions into individual proclivities, or to suggest that social classes or strata ought to be either self-conscious or politically united. Instead, it seeks to illustrate how conflicting economic interests and social relations can support rival political platforms and economic policy programmes which, in turn, tend to be expressed through alternative political parties, organizations and movements. Following Nicos Poulantzas $(1974,1975)$, the first fraction may be called the large internal bourgeoisie. It includes the owners of large firms across manufacturing, construction, agribusiness, food processing, shipbuilding, banking and other sectors. The main goal of this fraction is to shore up its own economic and political position within Brazilian dependent capitalism, which implies a relationship of cooperation as well as conflict with international capital and the internationalized fraction of the bourgeoisie (see below).

Even though segments of the internal bourgeoisie may be more or less closely related to international capital (e.g., finance is especially close; in contrast; construction is more autonomous), the internal bourgeoisie as a whole demands (different forms of) state protection to shore up its command of domestic markets and support its expansion abroad, especially in the Global South, and more advantageous deals with international capital. This fraction has, then, a contradictory relationship with state policy under neoliberalism. Whilst it tends to support neoliberal labour market and social policies for ideological reasons, it also recognizes that government intervention, basic social protections and rising minimum wages increase social cohesion and political stability, boost the 
domestic market and provide a protective umbrella against imperialist pressures. Consequently, while the internal bourgeoisie usually demands 'fiscal rectitude' and a large role for the private sector, it also expects lower real interest rates, state investment in infrastructure and in research and development (R\&D), diplomatic assistance, subsidised loans from the Brazilian Development Bank (BNDES), preferential rules for state procurement and restrictions against foreign capital. This fraction also rejects the wholesale liberalization of trade and capital flows because these policies threaten its own competitive position.

The internationalized bourgeoisie includes the representatives of economic groups owned by foreign capital and the domestic firms directly dependent upon them. They comprise international banks, insurance companies, large consultancy and accountancy firms, transnational and internationally integrated manufacturing capital, and - very importantly - the mainstream media. Although the media is almost entirely owned by domestic capital, it is committed ideologically to neoliberal financialization and the transnational integration of the Brazilian economy, and rejects the notion of a 'national' development strategy. The internationalized bourgeoisie was politically dominant during the administrations led by Fernando Collor (1990-1992) and Fernando Henrique Cardoso (1994-1998, 1999-2002). Their political project is anchored institutionally by policies of inflation targeting, central bank independence, the liberalization of international capital flows, privatizations and market 'deregulation', the dismantling of state capacity to allocate resources and steer development, and the rejection of state-led (re)distribution. This group is represented politically by the (misnamed) Brazilian Social Democratic Party (Partido da Social Democracia Brasileira, PSDB) and its allies (see below).

In addition to this primary division at the top, the Brazilian bourgeoisie also includes a large number of small and mediums-sized capitals lacking economic power, independent organization and autonomous influence. 
The divisions within the bourgeoisie, sketched above, are complex and there is no neat separation between the two main fractions and between them and the small and medium capitalists, who may belong to production chains dominated by the internal or the internationalized bourgeoisie, or associated to both in distinct ways. For example, the automobile dealerships are dominated by medium-sized domestic capital that is obviously dependent on the transnational automakers; however, the latter have significant autonomy vis-à-vis their overseas head offices, while the dealers are also closely connected to parts manufacturers, banks and insurance companies dominated by Brazilian capital. Similarly, the domestic banks generally agree with their foreign counterparts on the supposed primacy of inflation targeting and central bank independence over neodevelopmentalist policies supporting higher levels of investment and consumption. The transnational manufacturers dominating the consumer durables sector are also politically close to the domestic producers of capital goods, despite tensions concerning the role of the domestic market, fiscal, monetary exchange rate policy, capital controls and so on.

There are also contradictions within each fraction; for example, disputes within the internal bourgeoisie between manufacturing and banks concerning the level of interest rates. Although these are normally secondary vis-à-vis the contradictions between the two main bourgeois fractions, they can affect the political intervention of specific sectors. This is precisely what happened to the sugar cane-ethanol chain. Ethanol has been used extensively to fuel Brazilian automobiles for more than three decades, and it drives a vast sugar cane industry that also supplies the domestic and external markets with sugar and provides inputs to the food, beverages and other industries. Having supported the two Lula administrations, the sugar cane-ethanol chain moved into opposition to Dilma Rousseff because her policies supported the rival oil chain built around (state-owned) Petrobras, Latin America's largest oil company (see below).

In general, then, the structural separations between the internal and the internationalised fractions of the bourgeoisie are tempered as well as strained by the overlapping cleavages between industrial and 
banking capital, domestic and foreign capital and large and medium-sized capital, as well as national, regional, sectoral, political and other imperatives which can generate variegated outcomes in practice. These often surface as political tensions (Farias 2009). 


\section{Political Forces}

The previous section has identified the two main fractions of the bourgeoisie and a fluid periphery around them. The orthodox neoliberal macroeconomic strategy implemented by Collor and Cardoso in the 1990s, and the hybrid neoliberal-neodevelopmentalist strategy of the PT administrations had a variegated impact upon those class fractions, the bourgeois periphery and other social groups. ${ }^{2}$ These uneven outcomes, and the political twists and turns during the consolidation of neoliberalism and democracy in Brazil, since the late 1980s, eventually led to the emergence of stable forms of expression of the interests of the two main fractions of the bourgeoisie. Brazilian political life has become polarized accordingly. On the one hand, the internationalized bourgeoisie and international capital are associated with the orthodox neoliberalism expressed by the PSDB and the mainstream media. The PSDB introduced and managed orthodox neoliberal policies in Brazil, which, just as elsewhere, curtailed social and labor rights, privatized and denationalized state-owned enterprises, and deregulated both finance and external trade. ${ }^{3}$ In contrast, the internal bourgeoisie has become identified with the hybrid policies of the PT.

During the PT federal administrations, since 2003, Brazil's development strategy shifted to include the hybrid combination of elements of neoliberalism and Latin American neodevelopmentalism. At a fundamental level there is policy continuity, since the PT maintained the macroeconomic "policy tripod' introduced by Fernando Henrique Cardoso in 1999, including inflation targeting and central bank independence, floating exchange rates and liberalized capital movements, and contractionary fiscal and monetary policies. These policies have had a consistently adverse impact on the internal bourgeoisie; for example, high interest rates and demand contraction have fuelled the overvaluation of the currency (the real) and led to deindustrialization and the loss of export competitiveness especially in manufacturing. They have also created a declining trend in investment and GDP growth rates. 
These macroeconomic policies were not removed by the PT administrations, but they were toned down and, in the second Lula administration, 'hybridized' through the introduction of elements of neodevelopmentalism running in parallel with (or placed uneasily on top of) those neoliberal policies (Saad-Filho and Morais 2011, 2014). The hybrid policies included, first, the closer alignment of (neoliberal) monetary and exchange rate policy with the government's (neodevelopmentalist) industrial policy in order to limit the current account deficit and support the internalisation of important production chains. Second, real interest rates fell to their lowest levels in 20 years (from an average of 22 per cent, in Cardoso's first administration, to less than 3 per cent under Dilma), and the Central Bank extended significantly the maturity and lowered the costs of the domestic public debt. Third, the contractionary impact of high interest rates was further neutralized by the capitalisation of BNDES, which offered subsidised loans to a rapidly expanding set of enterprises (see below). Fourth, the earlier liberalization of imports was tempered by a 'local content' policy favoring domestic producers in government and SOE procurement. Fifth, the SOEs that survived the neoliberal 'cull' in the 1990s were strengthened, especially Petrobras. Sixth, the government implemented successive rounds of tax rebates to stimulate production and control inflation, in a significant departure from the single-minded focus on the manipulation of interest rates under neoliberalism; the Rousseff government also strong-armed the private operators into reducing the price of electricity. Finally, in order to commit the internal bourgeoisie to higher levels of investment in transport and infrastructure, and to bypass budgetary constraints and legal limitations to state funding, the government offered regulatory changes and concessions and supported many public-private partnerships. These policies unquestionably reinforced the position of the internal bourgeoisie in the power bloc; conversely, this fraction became Lula's strongest source of support as he confronted the growing hostility of international capital.

Despite the apparently wide scope of these policy changes, the internal bourgeoisie never aimed for more than the moderation of the harshest features of neoliberalism. The internal bourgeoisie does not have an independent accumulation strategy, and it does not seek to impose a narrow hegemony 
marginalising the internationalized bourgeoisie. The internal bourgeoisie remains heavily dependent on imperialism at the levels of ideology, culture, technology, finance and politics, and it does not aim to break away from it; it only wants a more comfortable position within global imperialism and in the Brazilian power bloc. In contrast, the internationalized bourgeoisie does have an expansive strategy aiming at the complete subsumption of the internal bourgeoisie through the ruthless implementation of neoliberal macroeconomic policies. It follows that the conflict between the two main fractions of the bourgeoisie is deeply asymmetrical.

Both fractions of the bourgeoisie have established important alliances outside the power bloc. It was mentioned above that the internal bourgeoisie leads the political front supporting the PT administrations. This alliance includes the lower middle class, the unionized workers, most organised peasants and the majority of the informal and marginalized workers (Saad-Filho and Boito 2016). While they have consistently privileged the interests of the internal bourgeoisie, the PT governments have also brought significant gains to those social groups, leading to a significant improvement in their living and working conditions. These gains include rising minimum wages, the expansion of welfare transfers and benefit payments, protection to family agriculture, the expansion of universities and professional schools, the introduction of racial and social quotas for access to universities and the civil service, public housing programmes, lower tariffs and expanded access to the electricity grid, and so on. Those policies and programmes have benefitted especially the informal sector workers who, in turn, have been the most reliable base of support to the PT presidential candidates (Singer 2012). For example, in the 2014 presidential elections Dilma Rousseff won because of the support of the informal workers, despite the faltering support or even withdrawal of other groups from the neodevelopmentalist front.

In turn, the internationalized bourgeoisie has established a robust alliance with the urban upper middle class. This social group includes the managers of most large and medium-sized private firms, the high cadres of the state bureaucracy (judges, prosecutors, senior administrators, high-ranking military and 
police officers, etc.; see below), skilled professionals offering non-reproducible services (lawyers, doctors, dentists, engineers, academics, architects, artists, and so on), independent merchants, smallscale rentiers and commercial landowners, and entrepreneurs hiring a small number of workers, often family members. The upper middle class is, then, a heterogeneous group connected indirectly to the dynamic core of capitalism; they do not have the economic power of the bourgeoisie or the political power of the organized workers. However, the upper middle class has the economic and cultural wherewithal to articulate its demands through the political system, the media, some trade unions, NGOs, lobbies and the justice system. Consequently, they can express their economic interests and ideological prejudices powerfully, even though they may be diverse, reactionary, internally inconsistent or strategically untenable (Chauí 2013, and Pomar 2013, pp.43-44).

Since the start of the neoliberal transition, in the late 1980s, the Brazilian upper middle class has gradually assimilated a capitalist ethics of competitiveness, accumulation and exclusion that, eventually, turned them into the main mass base of support of the PSDB. This social group sees in the social policies of the PT governments a direct threat to its economic position and social standing. This is understandable. The upper middle class has been badly squeezed by the exhaustion of importsubstituting industrialisation in the early 1980s, the subsequent slowdown of economic growth, the retreat of secure and well-paid occupations since the neoliberal transition, and the low-wage intensity of the country's economic recovery since the mid-2000s. At the same time, the upper middle class has become enthralled by the notions of cultural and economic 'globalisation' peddled by the media and superficially experienced in its (historically recent) forays abroad.

The distributional policies implemented by the PT have nearly doubled the minimum wage (which is a cost for the upper middle class, as a net buyer of low-end personal services), introduced means-tested transfer programmes funded by general taxation (which the upper middle class helps to fund but cannot claim), incorporated millions of workers into formal labour markets (raising both costs and demand, especially in the services sector), diluted the near-monopoly of higher education and 'good 
jobs' of the upper middle class through the explosive growth of the universities and the quotas for blacks and students from state schools, ${ }^{4}$ and introduced recruitment quotas in the civil service. More recently, the Rousseff administration extended employment rights to domestic workers, including house cleaners, nannies, cooks, drivers, gardeners and personal security guards that are widely employed in upper middle class households. This policy has raised costs to their employers and, potentially more significantly, threatens the authoritarian and paternalistic relationships in their households. The Rousseff administration also created, in 2013, a health programme bringing thousands of foreign (mainly Cuban) doctors to Brazilian municipalities without any health facilities. Despite the heavily circumscribed conditions in which these doctors were hired, the programme was opposed by all medical associations in the country, drawing upon a grotesque racist and anticommunist discourse. Finally, in addition to these targeted programmes the PT governments have also accommodated an emerging cycle of industrial action since the mid-2000s that has greatly improved the earnings of millions of skilled workers (Boito and Marcelino 2011).

Those gains favouring the poor have transformed the country's pattern of demand and, correspondingly, a whole host of institutions that used to be monopolized by the (white) upper middle class. Airports, medical facilities, shopping malls, bars and restaurants have been 'overrun' by lowincome workers and relatively poor black people that, previously, simply could not access them.

The encroachment of the workers and the poor upon the economic, social and geographical privileges of the upper middle class has generated intense anxiety and fierce opposition. For example, the social media has been bubbling for years with expressions of discomfort with this unwanted social and racial mix. In essence, the upper middle class seems to consider that their privileges are due to hard work and personal merit; conversely, low-income workers are lazy and their abject living conditions are simply the inevitable - and fully deserved - outcome of their preference for leisure. It follows that the poor are generally undeserving of taxpayer-funded support, and that cash transfers and other welfare programmes are doubly wrong: they reward laziness and perpetrate injustice against meritorious 
wealth-creators. In response to the economic and social advance of the poor, the upper middle class has gravitated increasingly towards the political right. This shift is highly significant, since the upper middle class plays an important role securing the ideological hegemony of the bourgeoisie through schools, universities, churches and the media, which are normally managed by these professionals. 


\section{The Political Regime}

It was shown above that the power bloc in Brazil is dominated by two (conflicting) fractions of the large bourgeoisie, that is, parts of the upper layer of the capitalist class. To this limited social condominium corresponds a relatively closed political system that concentrates decisions in the Federal Executive, headed by the President of the Republic. The President's central position inevitably personalizes the country's political life. In other words, in Brazilian democracy, decisionmaking is irreducibly authoritarian. This paradox has been called 'hyperpresidentialism', or 'civilian authoritarianism' (Saes 2001, Torre 1996).

Congress, including a Chamber of Deputies and the Senate, occupies a subordinate position in the formulation and implementation of public policy. Despite its formal importance, the influence of Congress remains limited because the Presidency has appropriated most legislative functions through the 'provisional measures' (medidas provisórias). These are effectively presidential decrees awaiting ratification by Congress, and they have been used extensively since the 1988 Constitution. In addition to the provisional measures, the Executive generally controls the Congressional agenda through the concentration of power on the Speakers of the Chamber and the Senate, which are elected by their peers but, effectively, appointed by the President (as long as s/he can command, badger or bargain the support of most Deputies and Senators). Legislative power is concentrated at a further level because the Speakers and party leaders control the voting process through their right to bestow 'urgency' (regime de urgência) upon bills they wish to bring to a vote; in turn, the leaders often vote on behalf of their parties while the Executive bargains directly with them, offering favours in exchange for block votes. One of the symptoms of the crisis of the Rousseff administration, in 2015, is the unusual autonomy of the Speakers of the Chamber and the Senate and their aggressive use of constitutional prerogatives against the Executive. This is unusual, and it is certainly not how the legislative process is meant to happen. 
Most political parties exist only as more or less coherent block votes in Congress; otherwise, they are largely marginalized from all levels of the state. It follows that Brazil does not have government by parties, but parties of government. For example, during the administrations of Fernando Henrique Cardoso the main task of the PSDB was to secure Congressional approval for government decisions whose content the party often ignored entirely. This is substantively identical to what happened to the PT during the Lula and Rousseff administrations.

This was unexpected, since the PT emerged in 1980 as an independent mass party of the left; it was closely linked to the trade unions and to a new generation of mass movements. Its utter subordination to federal administrations nominally elected by the party itself illustrates the strength of civilian authoritarianism in Brazil: there is no question that the upper layers of the state bureaucracy hold more power than 32 political parties and their elected representatives. Indeed, only about half a dozen parties have a semblance of political life; the others are either trading entrepots for parliamentary votes or vehicles supporting narrow (often personal) agendas.

Apart from voting in Congress, the political parties are relevant only in the run-up to the elections. This does not imply that most candidates are controlled by 'their' parties. For example, article 147 of the statutes of the PT states that if there are competing pre-candidates for President of the Republic, Governor, Senator or Mayor, the party's candidate will be selected through an internal ballot. In reality, however, a committee chaired by Lula has handpicked key PT candidates since the 1990s. Lula personally chose Dilma Rousseff as his successor in 2010, and he decided that the party would support her re-election in 2014. Lula also regularly chooses the PT candidates for Mayor of São Paulo city and Governor of São Paulo state, the country’s wealthiest and most populous administrative units. It is identical with the PSDB, where a small number of leaders monopolises decisions. Internal debate is the exception in both parties, and it rarely touches on anything that matters. 
PT and PSDB have polarized Brazilian presidential elections since the early 1990s. Their rivalry is a reflex of the conflict between the two bourgeois fractions examined above. Correspondingly, these parties recruit members in distinct social sectors (Rodrigues 2009), and their voters have distinct socioeconomic profiles (Singer 2012). The PSDB won the presidential elections in 1994 and 1998, while PT won in 2002, 2006, 2010 and 2014. No other party even reached the second round in these six elections (in 1989 the PT narrowly lost the second round of the first presidential election after the dictatorship to Fernando Collor, who had virtually no organised support).

The fragmentation of Brazil's political system is fostered by the coexistence of elections in two rounds for executive positions, in parallel with proportional representation for the legislature (Duverger 1967). In turn, the polarization between PT and PSDB expresses the consolidation of a multiparty system dominated by these two large parties. Each of them has a set of preferential alliances with 'satellite' parties and, as long as political life remains stable, most of these minor parties exist only to provide advantages, jobs and financial gain to their leaders. Following Max Weber (1946), they are 'patronage parties', although they are not entirely devoid of ideology. They are nevertheless essential, as neither the PT nor the PSDB is ever likely to achieve a majority in Congress: up to two dozen patronage parties regularly control at least 200 seats out of 513 in the Chamber of Deputies and 81 in the Senate. They are essential for governability, but their mode of existence fosters the political evacuation of Congress and its subservience to the Executive. The limitations of Congress and the political parties, described above, make the legislative too heterogeneous and unreliable to organise the political hegemony of the bourgeoisie, and completely unable to address efficiently the conflicts within the power bloc. 


\section{Contradictions in the State Bureaucracy}

The concentration of decision-making in the Executive makes a small number of federal institutions centrally important instruments of political struggle. The rival fractions of the bourgeoisie constantly seek to capture these institutions in order to create, entrench and project their own power, promote specific policies and priorities, and disarticulate policies promoted by their rivals. The significance of each institution for this conflict depends on several factors, especially their relationship with the Presidency, its size, relevance and economic and political functions, the social composition of their staff, the correlation of political forces, and the political conjuncture.

The core of the Federal Executive comprises the Presidency and key economic and political Ministries, which conceive, implement and monitor the country's development strategy. In turn, several subordinate institutions can play a significant role implementing or resisting against that strategy. A brief examination of some institutions can illustrate their significance. The internal bourgeoisie has a strong power center in the large SOEs, especially BNDES and Petrobras and, at a further remove, two state-owned commercial banks, Banco do Brasil and Caixa Econômica Federal. In contrast, the internationalized bourgeoisie dominates the judiciary, the Attorney General's Office and the Federal Police, which have become centers of resistance against the PT. Just like the dispute between PT and PSDB, the conflict between these institutions also expresses the rivalry between bourgeois fractions at the heart of the state. 


\section{(A) BNDES, Petrobras and the Internal Bourgeoisie}

BNDES and Petrobras are highly significant for the internal bourgeoisie, as they have been centrally important in the implementation of the neodevelopmentalist policies that neutralised, in part, the neoliberalism imposed by the internationalized bourgeoisie.

Lula appointed Luciano Coutinho, a well-known heterodox development economist, President of BNDES in 2007. Coutinho has recently become the longest-serving President of the institution since its foundation in the 1950s. Under his chairmanship the BNDES loan portfolio has expanded tenfold, and it has become the largest development bank in the world, comfortably surpassing the World Bank. The expansion of BNDES allowed the Lula and Rousseff administrations to offer subsidised loans to selected firms, especially those targeted to become 'national champions', that is, nurtured to take up leading global positions (Bugiato 2014). For example, BNDES loans transformed JS-Friboi into the world's largest company in the processed meats sector. The firm has purchased processing plants in four continents, and its rapid expansion provides the best example of success of the PT's neodevelopmentalist industrial policy. In addition to subsidised loans, BNDES has also supported investment by large domestic firms through its subsidiary, BNDES-Par, which invests directly in selected firms. BNDES loans and BNDES-Par share purchases were funded through transfers by the National Treasury. However, by convention these transfers count as public sector spending rather than investment; the ensuing reduction of the primary fiscal surplus (required to service the domestic public debt) was bitterly criticized by international finance and the PSDB, regardless (and perhaps because) of the developmental, income, employment and export outcome of these loans and investments.

The Lula government also supported Brazilian 'national champions' through diplomatic agreements with other countries in the Global South, especially in South America and sub-Saharan Africa. Several countries have obtained BNDES loans for infrastructure, especially roads, dams and railways, on 
condition that those projects were led by Brazilian companies. In doing this, the PT administrations have established a close relationship between Brazilian foreign policy and the internal bourgeoisie (Boito and Berringer 2014; Fontes and Garcia 2014). A successful example is the Port of Mariel, in Cuba, which incited loud criticism from the PSDB. This port was built by a consortium of 300 firms led by Odebrecht Engineering, one of the largest Brazilian construction companies. The celebration of the completion of phase 1 of the work, in January 2014, was attended by most left-wing heads of state in Latin America, including Bolivia’s Evo Morales and Venezuela’s Nicolás Maduro.

Petrobras was the other key lever of the PT's neodevelopmentalist economic policies. While BNDES attempted to bypass the financing bottleneck confronting Brazilian capital due to high interest rates and the reluctance of banks to finance investment, Petrobras introduced a new procurement policy to counteract the impact of import liberalization on domestic production and support import substitution in the oil and gas chains. Lula announced this policy change in his 2002 presidential campaign; it committed his government to the internalisation of the manufacture of oil tankers, drill rigs, deepwater platforms and other equipment for Petrobras. This policy was spectacularly successful. The Cardoso administration had reduced drastically the funding available to the oil industry in the 1990s, and compelled Petrobras to import most of its equipment and services. By 2003, the Brazilian shipbuilding industry employed only 4,000 workers. The policy reversal under Lula drove a strong recovery of the shipyards, which reached 100,000 workers in 2014; mothballed shipyards in Rio de Janeiro were reopened, and new ones started operations in the Northeast and the South (Gomes 2015).

This recovery strategy was implemented by Sergio Gabrielli, a neodevelopmentalist engineer appointed President of Petrobras in 2005 (he stayed in office until 2012). In addition to the new procurement policy, Gabrielli ramped up the company's investment on R\&D, oil exploration and refining, in contrast with the firm's focus on financing the oil sector during the Cardoso administration. A transformative outcome of this policy was the discovery of deep-sea 'pre-salt' oilfields in the South Atlantic, holding estimated reserves of 28-35 billion barrels. ${ }^{5}$ Lula and (then) 
Energy Minister Dilma Rousseff imposed a new oil extraction policy in the late 2000s that required Petrobras to participate in all new oilfields. This policy replaced the concessions to the large oil transnationals introduced under Cardoso. The new policy was heavily criticized by foreign capital and the PSDB, but it led to the rapid expansion of Petrobras operations ('pre-salt' oilfields are currently producing 800,000 barrels per day), and the simultaneous increase of oil rents appropriated by the State. These are being paid in a Sovereign Fund that will support health and education spending. In turn, the shipbuilding chain is both large and highly diversified. It includes not only the shipyards but also mechanical and electrical engineering, heavy construction and a host of other sectors (Sabença 2014). The expansion of this chain is one of the most significant achievements of the industrial policy of the PT administrations: it has brought together the interests of hundreds of domestic firms in multiple sectors, assisted the development of domestic science and technology, and was supported by large trade unions because of its employment impact. The expansion of the Brazilian shipbuilding chain provides a textbook example of successful neodevelopmentalist policies supported by a multi-class political front. However, similar outcomes could not be achieved in other sectors. For example, in traditional manufacturing sectors, especially textiles, footwear and apparel, local production has suffered badly because of Asian imports since the early 1990s, and the industry has failed to recover. In sectors with a higher technological content, especially automobiles, computers, household appliances and electronic goods, foreign capital has traditionally been dominant, and domestic firms operating along the intermediate links of the chain have lost market share because of technological change and the transnationalization of production since the transition to neoliberalism. 
The PSDB leadership has criticized consistently government policies towards BNDES and Petrobras and, inevitably, these institutions themselves. Fernando Henrique Cardoso, José Serra and other party leaders have complained repeatedly against these power centers of the internal bourgeoisie (Cardoso 2015, Serra 2013). They claim that their expansion compromises the government's fiscal targets, fuels inflation and is non-transparent (i.e., corrupt) and undemocratic; they suggest that BNDES has extended loans based on political rather than technical criteria, that Petrobras investment plans are overambitious, and that the demand that Petrobras must operate in every oilfield reduces foreign investment in Brazil and 'pre-salt' oil production. Finally, they state that the local content policy requiring Petrobras to purchase $65 \%$ of its inputs from Brazilian firms is anachronistic, inefficient, raises costs and will hamper the firm's technological development.

These disputes around BNDES and Petrobras illustrate the argument, made above, that the Brazilian political process pivots around the conflict between the two fractions of the bourgeoisie, and that this conflict drives the ideology and discourse of the main political parties. In other words, neoliberalism and neodevelopmentalism express, at the level of ideas, the interest of rival bourgeois fractions. Although it may seem odd that PSDB, a thoroughly bourgeois party, opposes policies supporting large firms in the shipbuilding, construction, engineering, food, steel and other sectors, the party's principal commitment is not with domestic capital as a whole but, specifically, with international capital and finance and with local capitals closely integrated with them. Conversely, the PT, overtly a party of the working class, has become the main political vehicle of large domestic capital and the driving force of a developmentalist alliance that is similar, both in aims and composition, to the 'national fronts' advocated by Communist Parties in Brazil and elsewhere in the 1950s-60s (see Boito 2013).

These political conflicts have evolved recently. While the economy was growing and the PT administrations enjoyed strong political support, in the mid- and late-2000s, the PSDB leadership 
found itself isolated; their orthodox neoliberal discourse had little traction. However, since 2011, the Brazilian economy has slowed down, new social and political conflicts have emerged and old ones returned with a vengeance (Saad-Filho and Boito 2016). In this context, the PSDB and the mainstream media have not only stepped up their attacks against the PT, but also mobilised the judicial system in support of their strategy of aggression. Three features of the judiciary, the Federal Police and the Attorney General's Office incline them to support the internationalized bourgeoisie and the upper middle class against the internal bourgeoisie, the PT and their allies.

First, these institutions employ the most privileged civil servants in Brazil; their 40,000 judges, prosecutors, attorneys and top bureaucrats are comfortably stationed at the top of the upper middle class. The starting salary of a public prosecutor ranges between 29 and 38 times the monthly minimum wage for a working week of 25 hours, with additional work counting as overtime. ${ }^{6}$ It is similar with judges, who earn around 40 times the minimum wage; they also receive generous food allowances and housing support, even when they are homeowners. ${ }^{7}$ Although the top layers of BNDES and Petrobras employees are also well paid, their salaries are far lower than those in the judiciary.

The second distinguishing feature of the judiciary and the Federal Prosecution is that they enjoy full administrative and financial autonomy: they are funded by general taxation but are accountable only to themselves, as the judicial system is not subject to any form of control by the federal government. Judges and prosecutors can even set their own salaries.

The third reason why these institutions tend to lean against the PT is their structural function in the capitalist state: keeping public order. They are what Pierre Bourdieu (1998) called 'the right hand of the state'. This function tends to position their staff in opposition to governments that facilitate popular organization and that accommodate movements deploying 'illegal' forms of struggle, for example, occupations of arable land and urban spaces, roadblocks, and so on. 
The mainstream media, judges, prosecutors, attorneys and the top levels of the Federal Police have joined the PSDB leadership in two systemic attacks against the PT administrations. In 2005 and, again, in 2015, operations by the Federal Police, the public prosecution and the judiciary against corruption, spurred by the media and the PSDB, have triggered political crises threatening the destruction of the PT. Their operations have targeted key institutions of neodevelopmentalism, especially BNDES and Petrobras. Those vicious attacks were facilitated by the inexplicable deference of the PT towards the media and the judiciary: the PT has always refused to mobilize its social base to counter the biased and illegal treatment inflicted upon the party and its members in positions of government, as was recently illustrated by the Petrobras scandal.

In 2014, it emerged that a cartel of construction companies bribed a small number of politically appointed directors of Petrobras in order to secure a virtual monopoly of oil-related contracts. The Brazilian construction sector is heavily concentrated around 15 large (mostly family-owned) firms that emerged in the late 1950s, during the construction of the new capital, Brasília. Those firms expanded rapidly during the military dictatorship (1964-85), and they currently dominate the market for public works (Sabença 2013). Bribes allegedly allowed those companies to capture and allocate hundreds of contracts to the cartel members; in turn, the corrupt directors of Petrobras channelled part of those funds to the political parties supporting their appointment.

High-ranking Federal Police and public prosecution officers made clear political use of this investigation. They ignored clues suggesting the involvement of the PSDB in similar cases, selectively leaked classified or misleading information to competing media organisations, and consistently sought to compromise the PT especially the run-up to the 2014 presidential elections. They also illegally arrested company executives in order to compel them to enter plea bargains; those refusing the offer to cooperate with the investigation were kept in prison indefinitely. In doing this, the Federal Police and the public prosecution ensured that the investigation would always be in the headlines and, eventually, 
it became a telenovela - another farcical soap opera dominating Brazilian evening television. At the same time, the PSDB created a parliamentary committee to investigate corruption at Petrobras, further escalating the confrontation. The mainstream media started speculating about the impeachment of Dilma Rousseff while, at the same time, claiming that the only way to end corruption at Petrobras is to eliminate the domestic procurement policy and remove the rule that the company must participate in all oilfields. The PSDB immediately introduced bills in Congress to impose those policy changes, which must have pleased the large oil transnationals and the large shipyards and oil and gas contractors in the USA, Asia and the EU.

European capital has rushed to lay claim to the construction sector. In an article in the newspaper $O$ Estado de S. Paulo, EU Trade Commissioner Cecilia Malmström makes brief remarks about the spread of corruption in Brazilian public works, in order to conclude that the EU would only sign a trade deal with Mercosur if its own firms have greater access to this (presumably tainted) market. Sadly, the Commissioner failed to mention the cases of Siemens and Alstom, which admitted making large payments to PSDB politicians in order to win contracts for the São Paulo rail and metro systems. Interestingly, this scandal never raised judicial or police eyebrows in Brazil. In turn, the EU Commissioner will certainly be pleased with the 'independence' of the Brazilian judiciary if, because of the Petrobras scandal, the largest domestic construction companies are rendered ineligible for public contracts.

The goals of international capital and the integrated fraction of the Brazilian bourgeoisie harm not only the internal bourgeoisie but, also, the workers employed in construction and in the oil and gas chains, which depend heavily on public investment in general, and on Petrobras specifically. The orthodox neoliberal agitation around corruption is, then, both partial and misleading. Its main goal is not political and administrative probity but, instead, to disguise the ambitions of the internationalized bourgeoisie and the upper middle class. Their discourse and the judicial investigations are both selective: they target only the institutions and parties aligned with neodevelopmentalism, showing that 
their aim is government policy rather than corruption. This cover-up is necessary because, in a democracy, minority interests can prevail only if they command mass support. If the neoliberal campaign were to admit that its goals are to weaken Petrobras and eliminate the local content policy, it would fail completely. In contrast, agitation against corruption allows the internationalized bourgeoisie and the upper middle class to hijack popular revulsion against white-collar crime in order to smuggle in policy changes against the interests of the vast majority, and to shift the relation of forces within the power bloc to their own advantage. 


\section{Conclusion}

The bourgeoisie is not a homogeneous class, and the State is not a passive instrument in the hands of any government, class, or fraction. The implications of this claim are examined in this article through the conflict between the internationalized bourgeoisie and the internal bourgeoisie, that has dominated political life in Brazil during the PT administrations. Just like the upper middle class, the broad (formal and informal) working class cannot ignore this conflict. The neodevelopmentalist policies of the internal bourgeoisie support limited income and employment gains for the majority and help to improve the conditions for further struggle; in contrast, the neoliberal policies of the internationalized bourgeoisie would intensify the concentration of income and the social, economic and political decomposition of the working class.

The limited and asymmetric conflict between the two fractions of the bourgeoisie has evolved within an authoritarian bourgeois democracy. Instead of deepening, expanding and radicalising democracy in order to reinforce their claim to power, the PT administrations have become increasingly entangled with, and within, the institutions of the state, and ever more distant from the traditional social base of the Workers' Party in the working class and the radicalised urban middle class. This was due to the mistaken belief that the PT could govern peacefully and implement a potentially open-ended programme of social-democratic reforms if it only occupied the top layer of a limited number of state bureaucracies, and managed to avoid paralysing institutional conflicts with the ruling class.

This was always going to be a highly unlikely outcome, and it did not come to pass. The internationalized bourgeoisie and the upper middle class, whose interests control the media and the judiciary (the latter being the penultimate line of defence of the established order, the last being the armed forces) - have turned against the PT's mild reformism and paralysed the administration of Dilma Rousseff. 
The question that cannot be answered at this stage is whether or not the PT could have deployed the tools of Executive power, in conjunction with a mass social movement, in order to turn established privileges into social rights and leverage the democratisation the Brazilian state. This would have taken the Brazilian experience closer to those unfolding in Bolivia and Venezuela although, obviously, under very different circumstances and with unpredictable results. It is now much too late to do that, and still too soon to consider what might have been. 


\section{References}

Barrow, Clyde

2002 “The Miliband-Poulantzas Debate: An Intellectual History”, in: Stanley Aronowitz and Peter Bratsis (eds.) Paradigm Lost - State Theory Reconsidered. Minneapolis: Universty of Minnesota Press.

Boito, Armando

2012 “Governos Lula: a Nova Burguesia Nacional no Poder”, in Armando Boito and Andréa Galvão (eds.) Politica e Classes Sociais no Brasil dos Anos 2000, São Paulo: Alameda.

Boito, Armando

2013 “O Lulismo é um Tipo de Bonapartismo?”, Crítica Marxista 37.

Boito, Armando and Tatiana Berringer

2014 'Social Classes, Neodevelopmentalism, and Brazilian Foreign Policy under Presidents Lula and Dilma”, Latin American Perspectives, 41, pp.94-109.

Boito, Armando and Paula Marcelino 2011 "Decline in Unionism? An Analysis of the New Wave of Strikes in Brazil", Latin American Perspectives, 38 (5), pp.62-73.

Bourdieu, Pierre 1998 Contre-Feux - Propos pour Servir à la Résistance Contre L'invasion Néo-Libérale. Paris: Éditions Raisons d"Agir. 
Bugiato, Caio

2014 "A Política de Financiamento do BNDES e a Burguesia Brasileira”, Cadernos do Desenvolvimento, 9 (14), pp.83-103.

Cardoso, Fernando Henrique

2015 "Desvendar a Trama”. O Estado de S.Paulo, 3 May.

Chauí, Marilena

2013 Uma Nova Classe Trabalhadora, http://www.cartamaior.com.br/templates/materiaMostrar.cfm?materia_id=22284\&utm_source $=$ emailmanager\&utm_medium=email\&utm_campaign=Boletim_Carta_Maior_03072013

Clarke, Simon (ed.)

1991 The State Debate. London: CSE/Macmillan.

Duverger, Maurice

1967 Les Partis Politiques. Paris, Armand Colin.

Farias, Francisco Pereira de

2009 “Frações Burguesas e Bloco no Poder”, Crítica Marxista, 28, pp.81-98.

Filgueiras, Luis and Elizabeth Oliveira

2013 "A Natureza do Atual Padrão de Desenvolvimento Brasileiro". Anais do XVIII Congresso da Sociedade de Economia Política,

http://www.sep.org.br/artigos/download?id=2148\&title=A+natureza + do + atual + padr $\% \mathrm{C} 3 \% \mathrm{~A} 3 \mathrm{o}+\mathrm{de}+\mathrm{d}$ esenvolvimento+brasileiro 
Fontes, Virgínia and Ana Garcia

2014 “Brazil's New Imperial Capitalism”, in: Leo Panitch and Greg Albo (eds.) Socialist Register. London: Merlin Press.

Gomes, Julia

2015 “Conteúdo Local e Neoliberalismo Neodesenvolvimentista: A Indústria da Construção Naval e a Política de Compras da Petrobrás durante os Governos Lula”. Unpublished manuscript.

Morais, Lecio and Alfredo Saad-Filho

2011 “Brazil beyond Lula: Forging Ahead or Pausing for Breath?”, Latin American Perspectives, 38 (2): 31-44.

Morais, Lecio and Alfredo Saad-Filho

2012 "Neo-Developmentalism and the Challenges of Economic Policy-Making under Dilma Rousseff”, Critical Sociology 38 (6):789-798.

Pomar, Wladimir

2013 “Debatendo Classes e Luta de Classes no Brasil”, http://novo.fpabramo.org.br.

Poulantzas, Nicos

1974 Les Classes Sociales dans le Capitalisme d'Aujourd'hui. Paris, Seuil.

Poulantzas, Nicos (1975) La Crise des Dictatures: Portugal, Grèce, Espagne. Paris, Maspero. 
Rodrigues, Leôncio Martins

2009 Partidos, Ideologia e Composição Social. Rio de Janeiro: Editora Centro Edelstein de Pesquisas Sociais.

Saad-Filho, Alfredo

2014 "Brazil: Development Strategies and Social Change from Import-Substitution to the 'Events of June'”, Studies in Political Economy 94, 2014, pp.3-31.

Saad-Filho, Alfredo and Armando Boito 2016 "Brazil: The Failure of the PT and the Rise of the "New Right'”, in: Leo Panitch and Greg Albo (eds.) Socialist Register. London: Merlin Press.

Saad-Filho, Alfredo and Deborah Johnston (eds.)

2005 Neoliberalism: A Critical Reader. London: Pluto Press.

Saad-Filho, Alfredo and Maria de Lourdes Mollo 2006 "Neoliberal Economic Policies in Brazil (1994-2005): Cardoso, Lula and the Need for a Democratic Alternative", New Political Economy 11(1), pp.99-123.

Saad-Filho, Alfredo and Lecio Morais 2014 “Mass Protests: Brazilian Spring or Brazilian Malaise?”, in Leo Panitch, Greg Albo and Vivek Chibber (eds.), Socialist Register, London: Merlin Press.

Saad-Filho, Alfredo and Galip Yalman 2009 Economic Transitions to Neoliberalism in Middle-Income Countries. London: Routledge. 
Sabença, Mariana

2014 “As Grandes Construtoras e a Política Econômica nos Governos Lula e Dilma”, $38^{\circ}$ Encontro Anual da Anpocs, http://portal.anpocs.org/portal.

Saes, Décio

2001 República do Capital. São Paulo: Editora Boitempo.

Serra, José

2013 "Para Romper o Atraso e a Inércia”. O Estado de S.Paulo, 10 October.

Singer, André

2012 Os Sentidos do Lulismo. São Paulo: Companhia das Letras.

Torre, Juan Carlos

1996 “O Encaminhamento Político das Reformas Estruturais”, Lua Nova, 37.

Weber, Max

1946 "Class, Status, and Party" in: Hans Heinrich Gerth and Carles Wright Mills (eds.) From Max Weber: Essays in Sociology. New York: Oxford University Press. 


\section{Endnotes:}

${ }^{1}$ For an overview of Marxist theories of the state, see Clarke (1991). The well-known PoulantzasMiliband debate is reviewed by Barrow (2002).

${ }^{2}$ These development strategies and their social implications are surveyed by Morais and Saad-Filho ${ }^{2}$ These development strategies and their social implications are surveyed by Morais and Saad-Filho (2011, 2012) and Saad-Filho and Mollo (2006).

${ }^{3}$ For an overview of neoliberal policies and their implications, see Saad-Filho and Johnston (2005) and Saad-Filho and Yalman (2009).

${ }^{4}$ The university admissions quotas have generated not only diffuse opposition but organized resistance. For example, a campaign led by students and academics at the University of Brasilia culminated in a highly publicized case taken to the Supreme Court, which voted for the constitutionality of the quotas.

${ }^{5}$ These oilfields are located in the Atlantic Ocean, underneath approximately five miles of water, rock and salt (the latter was probably left after the evaporation of an earlier ocean). Reaching those oil deposits presents considerable technological challenges, making the extraction of 'pre-salt' oil relatively expensive.

${ }^{6}$ See Judiciário Brasileiro em Perspectiva -Associação dos Magistrados Brasileiros https://www.amb.com.br/portal/docs/pesquisa/Judiciario_brasileiro_em_perspectiva.pdf, and Portal Consultor Jurídico, http://www.conjur.com.br/2013-mai-09/agenda-concursos-74-vagas-promotorjustica-estados.

${ }^{7}$ Conselho de Justiça Federal - Secretaria de Recursos Humanos, http://www.cjf.jus.br/cjf/cjf/administracao-de-rh/tabelas-deremuneracao/magistrados/Tabela\%20de\%20Remuneracao\%202014\%20magistrado.pdf/view. 